ENTREPRENEURSHIP AND SUSTAINABILITY ISSUES

ISSN 2345-0282 (online) http://jssidoi.org/jesi/ 2021 Volume 9 Number 1 (September)

http://doi.org/10.9770/jesi.2021.9.1(38)
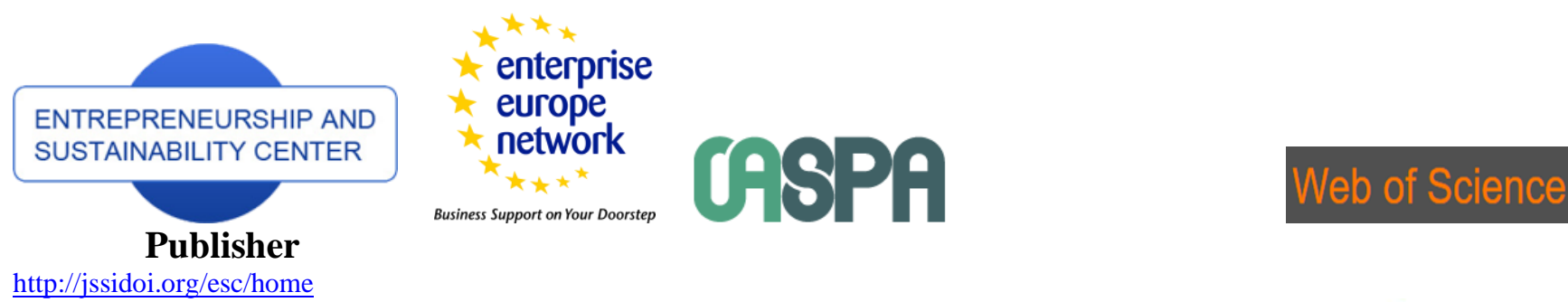

http://jssidoi.org/esc/home

1 Clarivate

Analytics

\title{
A VALUE PROPOSITION MIX FRAMEWORK OF SUCCESSFUL FOREIGN-OWNED SMALL AND MEDIUM ENTERPRISES IN SOUTH AFRICA
}

\author{
Mazanai Musara $^{1^{*}}$, Cecile Nieuwenhuizen ${ }^{2}$ \\ ${ }^{1}$ Faculty of Economics, Development and Business Sciences, University of Mpumalanga \\ Cnr. R40 \& D725, Riverside Mbombela, 1200 South Africa \\ ${ }^{2}$ DHET-NRF South African Research Chair in Entrepreneurship Education, College of Business and Economics, \\ University of Johannesburg, PO Box 524 Auckland Park 2006, South Africa \\ E-mails: ${ }^{1 *}$ mazanai.musara@ump.ac.za (Corresponding author); ${ }^{2}$ cecilen@uj.ac.za
}

Received 15 June 2021; accepted 25 August 2021; published 30 September 2021

\begin{abstract}
The paper presents the value propositions of successful foreign-owned SMEs in South Africa. The focus on successful foreignowned SMEs provides a stimulus for cross-cultural knowledge diffusion through internationalisation of entrepreneurial efforts by examining the currently under-studied value proposition construct within the SME sector. To achieve this aim, a multi-case empirical investigation, using the grounded theory approach, was conducted with a sample of forty-two successful foreign-owned SMEs in South Africa. The findings revealed that successful foreign-owned SMEs, in addition to commonly known value propositions (i.e product-based value propositions), have unique value propositions (customer interaction and business processes) that enable their businesses to succeed. A value propositions mix (VPM) framework for successful SMEs is presented, therefore, in this paper. The findings of this study are valuable in providing new insights into the VPM of successful foreign-owned SMEs to inform the broader development and sustainability of the SME sector operating within the African continent.
\end{abstract}

Keywords: value proposition mix; successful foreign-owned SMEs; cross-cultural knowledge diffusion

Reference to this paper should be made as follows: Musara, M., \& Nieuwenhuizen, C. (2021). A value proposition mix framework of successful foreign-owned small and medium enterprises in South Africa. Entrepreneirship and Sustainability Issues, 9(1), 612-632. http://doi.org/10.9770/jesi.2021.9.1(38)

JEL Classifications: L26

\section{Introduction}

The creation of unique value propositions is a key source of competitive advantage and central for successful business models (Osterwalder, Pigneur, Bernarda \& Smith, 2014; Teece, 2010; Vorbach, Müller \& Poandl, 2019). Osterwalder et al. (2014) noted that effective value proposition design enables the business to have a better understanding of the value creation patterns, as well as giving the business an opportunity to leverage its internal 


\section{ENTREPRENEURSHIP AND SUSTAINABILITY ISSUES}

ISSN 2345-0282 (online) http://jssidoi.org/jesi/ 2021 Volume 9 Number 1 (September)

http://doi.org/10.9770/jesi.2021.9.1(38)

capabilities and resources. These factors can be key sources of competitive advantage. As a result, the most important innovation activity of every business should be to strive to identify and create unique value propositions in order to create and retain sustainable competitive advantages. In SMEs, value propositions are vital as a means of identifying opportunities for growth and maintaining the overall sustainability of the business.

The significance of unique value propositions is widely recognized in general literature (for example see Payne \& Frow, 2014; Sengupta, Bamel \& Singh, 2015) and appreciated by practitioners, yet a clear understanding of value propositions in various business sectors is still lacking. The specific application of the value propositions' concepts in addressing the failure of SMEs, especially in the early business development stages, found limited expression in extant literature. Thus, this paper seeks to provide new insights into the value propositions of successful foreign-owned SMEs as well as to offer the value propositions mix (VPM) framework for SMEs. An understanding of the value propositions of successful foreign-owned SMEs that, despite the additional challenges that they face in the local market, continue to succeed, is central in broadening current knowledge of the said value propositions and increasing the scope of endeavors to address growth challenges among SMEs in South Africa. This paper is an exploratory study and, thus, does not attempt to provide a comparison with native-owned SMEs. The researchers, (referred to as 'we' or 'us' in future) therefore, sought new insights from the proprietors of the above mentioned successful foreign-owned SMEs.

In this paper, successful-foreign-owned SMEs are defined as businesses that are owned by foreign nationals in a host country, employing less than 250 employees; that have been operating for a period of more than three and a half (3.5) years, thus established SMEs were used (Herrington and Kew, 2016). Also, the success of SMEs was determined in terms of business performance using measures such as profitability, growth, market share, return on investment, number of employees and product lines (Radipere \& Dhliwayo, 2014).

Successful foreign-owned SMEs bring to the host nation the diversity of culture and knowledge needed for crosscultural learning and development (Radipere \& Dhliwayo, 2014; Tengeh, 2013). Compared to their locally owned counterparts, successful foreign-owned SMEs are susceptible to additional challenges to those experienced by native-owned SMEs, yet they continue to succeed (Tengeh, 2013). Previous studies, such as those conducted by Ndoro (2016), observed that successful foreign-owned SMEs conduct business differently from native-owned SMEs. For example, in the grounded theory study of foreign-owned SMEs by Chinese nationals, Ndoro (2016) revealed the unique opportunity identification mechanisms employed by these businesses. Similarly, Elo (2016:123) noted that international business, resulting from foreign-owned businesses, facilitates brain-gain and creates connecting flows and competitiveness. At the same time, the economic and social gains achieved by both the home and host countries are considerable (Nkongolo-Bakenda \& Chrysostome 2013). These findings espouse the view that successful foreign-owned SMEs are a source of new insights for the development of the broader SME sector. Also, the diversity of business sectors in which successful foreign-owned SMEs operate and the innovation propensity of foreign-owned SMEs (Ostrovsky \& Picot, 2020), create an opportunity for the diversity of perspectives to be used to develop a synthesized VPM for SMEs. Against this background, this paper sought to investigate the value propositions of successful foreign-owned SMEs in South Africa with the goal of developing a VPM that could be adopted by SMEs in South Africa and beyond.

Firstly, this paper provides theoretical perspectives on notions of foreign-owned SMEs and the concepts of value propositions to aid our understanding of the concept and its application in SME literature. Secondly, it discusses the methodology applied when gathering the empirical data used in this paper. The findings of the empirical investigations are then presented and discussed, together with an integrative framework of value propositions of SMEs. The article finishes with the presentation of the concluding remarks and the practical implications of the study. The following section delineates the concepts of value propositions. 


\section{ENTREPRENEURSHIP AND SUSTAINABILITY ISSUES}

ISSN 2345-0282 (online) http://jssidoi.org/jesi/

2021 Volume 9 Number 1 (September)

http://doi.org/10.9770/jesi.2021.9.1(38)

\section{Theoretical Perspectives}

This section presents theoretical perspectives on the notions of foreign-owned SMEs and value propositions. This information is important because it characterizes the nature of foreign-owned SMEs, the challenges that they face, and their contributions to economies globally. At the same time, it is important to conceptualize the concepts of a value proposition, as well as highlighting the important literature and theoretical perspectives relating to these concepts. The following subsection discusses the notions of foreign-owned SMEs.

\subsection{Foreign-Owned SMEs}

Foreign-owned SMEs have been studied in extant literature using name variations such as immigrant-owned SMEs and international new ventures (INVs) (Abrahamsson, Vanyushyn \& Boter, 2019; Prashantham, Kumar \& Bhattacharyya, 2019). Thus, extant literature provides clarity on the conceptualization of foreign-owned SMEs, regardless of the disparate definitions of SMEs in different contexts. There are country-level variations in terms of criteria for defining SMEs, with many countries using the number of employees and annual turnover as determining factors. Because of differences in currencies, which make comparability among countries difficult, the annual turnover criterion poses challenges when considering universally applied criteria. There, however, seems to be agreement in literature that the number of employees' criterion can be universally applied (Altman, Esentato \& Sabato, 2020; Cicea, Popa, Marinescu \& Stefan, 2019). Using the number of employees as a criterion for defining SMEs, many countries consider the figure of not more than 250 employees as the requirement for the business to be classified as an SME (Arthur, 2020; Takyi \& Naidoo, 2020). Combining the criteria of the number of employees and the country of birth, foreign-owned SMEs in this article are defined as businesses that are owned by foreign nationals in a host country, employing less than 250 employees.

The role of foreign-owned SMEs is widely acknowledged throughout the world (Kerr \& Kerr, 2020; NkongoloBakenda \& Chrysostome 2013). Kerr and Kerr (2020) in their study of foreign-owned firms in the United States of America (USA), revealed that over $25 \%$ of new firms in the USA are foreign-owned. A similar observation was noted in Canada where the innovative potential of foreign-owned SMEs translates into proportionately high numbers of new businesses that are started by foreign nationals (Ostrovsky \& Picot, 2020). In South Africa, the majority of foreign nationals are pressed into starting new businesses due to weak opportunities for formal sector employment, discrimination, lack of documentation and similar challenges, resulting in a proportionately large number of foreign-owned SMEs (Charman \& Piper, 2012; Radipere \& Dhliwayo, 2014). These numbers are even higher when opportunity-based immigrations to start new businesses in South Africa are also taken into consideration. Opportunity-based immigrations occur when foreign nationals move into another country to seek entrepreneurial opportunities. On the African continent, South Africa has long been a favourite destination for prospective foreign entrepreneurs due to its open policies competitive markets, and ease of conducting business (Asongu \& Odhiambo, 2019).

Due to their extraneous nature, foreign-owned SMEs are susceptible to additional challenges compared to their native-owned counterparts (Charman \& Piper, 2012; Radipere \& Dhliwayo, 2014; Radipere \& Dhliwayo, 2014; Tengeh, 2013). Charman \& Piper (2012) noted that, in addition to commonly known challenges facing SMEs in South Africa, successful foreign-owned SMEs, as previously indicated, are susceptible to discrimination, challenges in obtaining the relevant documentation (e.g. visas and permits), cultural barriers and stereotypes, as well as lack of community acceptance leading to xenophobic attacks. Nkongolo-Bakenda and Chrysostome (2013:7) referred to the challenges facing foreign-owned SMEs the "liability of foreignness" which results from the fact that foreign-owned SMEs incur "...unavoidable costs arising from sources, such as higher coordination costs, the foreign firm's unfamiliarity with the local culture and other aspects of the local market, a lack of information networks or political influence in the host country, or their inability to appeal to nationalistic buyers"). Despite these additional challenges, there are several successful foreign-owned SMEs in South Africa. 


\section{ENTREPRENEURSHIP AND SUSTAINABILITY ISSUES}

ISSN 2345-0282 (online) http://jssidoi.org/jesi/ 2021 Volume 9 Number 1 (September)

http://doi.org/10.9770/jesi.2021.9.1(38)

A question, therefore, arises as to what makes these SMEs succeed despite the additional challenges that they face. A good starting point for beginning to understand the source of their success would be to investigate the value propositions of these successful SMEs. This fact arises mainly because value propositions have been widely noted as a key source of competitive advantages (Payne \& Frow, 2014; Sengupta et al., 2015). The following section, therefore, presents theoretical perspectives on the concept of value propositions.

\subsection{The concepts of value propositions}

The concept of value propositions can be located within the broader business model literature. Acknowledging that the business model logic consists of interrelated dimensions that reinforce each other, the centrality of the value proposition dimension is undoubted (Amit \& Zott, 2012; Osterwalder et al, 2014; Priem, Wenzel, \& Koch, 2018; Zott, \& Amit, 2013). Priem et al. (2018) emphasized that value propositions and the resultant value creation as the conditio sine qua non for value capture is at the heart of any business model research. Similarly, Satar, Dastane, \& Ma'arif (2019) in their study of value propositions for e-commerce confirmed the central role that the value proposition in shaping the business's competitive advantages and ultimate success. Thus, understanding, designing, and delivering effective value propositions underlie the holistic business model logic and is indeed a key source of competitive advantage.

The concept of value propositions has been widely explored by many scholars in business models and marketing research literature (for examples see Frow \& Payne, 2011; Key et al., 2017; Osterwalder, Pigneur, Bernarda \& Smith, 2014; Payne, Frow \& Eggert, 2017; Trkman, 2019). The Marketing Research Institute's investigations noted the identification and development of value propositions as a priority research focus area for managers and scholars alike (Payne \& Frow, 2014). Similarly, Webster and Lusch (2013) argued that the marketing discipline needs fundamental rethinking and redefining of the essential premises and implicit models that have characterized the marketing discipline for over 50 years, in which the value proposition models are not an exception.

The concepts of the value proposition are anchored on the provision of value to the customers and other stakeholders (Wruk, Oberg, Klutt \& Maurer, 2018). It captures the values that a business promises to their target customers (Martin, 2016; Schor, 2017; Wruk et al., 2017). Gilles and Christine (2016) construed value as a multifaceted construct that integrates many aspects within, as well as beyond, the limits of a single business organization. In this regard, Fernandes, Martins, Campese and Rozenfeld (2019) identified the four categories of value, namely functional, emotional, change of life and social impact. The functional category is associated with the practical purposes of a product that reflects its function in the day-to-day lives of the relevant stakeholders. Emotional categories relate to the product's ability to generate positive emotions for stakeholders. Change of life comprises the product's capacity to influence the perspectives on which the stakeholders analyse the world. Social impact refers to the search for a common good, such as improvement of living conditions of people with whom the stakeholders have empathy (Fernandes et al., 2019). Considering all the different types of values, a value proposition, therefore, is a representation of the values that an organization promises its target customers (Martin, 2016; Schor, 2017).

One of the oldest conceptualization of value proposition is found in the seminal paper by Lanning and Michaels (1988) who suggested that a value proposition is a simple statement of both tangible and intangible benefits that the business provides to its customers. Lanning and Michaels's (1988) conceptualization of value proposition was premised on the business's value delivery system in which the business chooses, provides and communicates the value proposition to its customers.

Many definitions of value propositions found in the literature are based on the work of Lanning and Michaels (1988). For example, Johnson, Christensen and Kagermann (2008) describe a value proposition as a statement of 


\section{ENTREPRENEURSHIP AND SUSTAINABILITY ISSUES}

ISSN 2345-0282 (online) http://jssidoi.org/jesi/ 2021 Volume 9 Number 1 (September)

http://doi.org/10.9770/jesi.2021.9.1(38)

promise that a business formulates and adheres to solve a customers' fundamental dilemma of selecting between alternatives when making a purchase decision.

Despite its wide use in business models, marketing, and other related fields of study, Payne et al. (2017) noted that the concept of value proposition remains poorly understood by many scholars and managers. By extension, the application of the concept is also poorly executed both in literature and in practice (Katz, 2010; Skålén, Gummerus, Koskull \& Magnusson, 2014).

While extensive literature exists on the importance of value propositions, the literature on the value propositions of specific groups of firms, such as successful foreign-owned SMEs, is scant. Furthermore, relatively little research (Millspaugh \& Kent, 2016; Safar, Sopko, Bednar \& Poklemba, 2018; Zaborek \& Mazur, 2019) has been published on the application of the value proposition concepts in SME literature, especially in the African context. Yet, the concept of the value proposition is important in delivering, communicating and retaining company value to its customers. In their study, Safar et al (2018) broadly investigated the concept of the SME business model in the fourth industrial revolution in which they emphasized that this specific business model should include novel value propositions, value creation and value capture. However, the study did not offer a specific application context. In another similar study, Zaborek and Mazur (2019) studied the value proposition co-creation with consumers among Polish manufacturing and service SMEs. In this study, Zaborek and Mazur (2019) expressed the central role of value propositions among both manufacturing and service sector SMEs. Consequently, in this study the value proposition is being considered as a central component for business success within the broader business model logic (Osterwalder et al., 2014), and is being applied to the context of successful foreign-owned SMEs. Against this backdrop, this paper sought to investigate the value propositions of successful foreign-owned SMEs. The following section presents the research methodology applied in this study.

\section{Methodology}

Our methodology is founded on the Grounded Theory approaches of Strauss and Corbin (2008), focusing on the value propositions of successful foreign-owned SMEs in South Africa. With regard to the academic discussion in the preceding sections, Glaser and Strauss (1967) encouraged researchers to remain theoretically sensitive and to make use of existing insights while, at the same time, considering the emerging data. In this regard, a multistage non-linear approach to theoretical review was conducted (Hussein, Kennedy \& Oliver, 2017). Thus, the presentation of theoretical perspectives in the preceding sections does not imply that a literature review was conducted prior to conducting empirical investigations. Concurrent data analysis and a review of existing theoretical perspectives were conducted at different stages of the research process, thus, minimizing any possible preconceptions in grounded theory development. In this regard, we adopted an iterative process of concurrent data collection and data analysis following the guidelines provided by Collins and Hussey (2014). The iterative process emphasizes the relationships between data collection, coding, analysis and theoretical development (Collins and Hussey, 2014). The iterative process involved moving back and forth between stages throughout the concurrent data collection and analysis to develop the emergent theory.

The initial sample was selected using a judgemental sampling method in which SMEs who met the criteria of successful foreign-owned SMEs were selected. In this study, successful-foreign-owned SMEs are defined as businesses that are owned by foreign nationals in a host country, employing less than 250 employees, that have been operating for a period of more than three and a half (3.5) years, thus established SMEs were used (Herrington and Kew, 2016). Also, the success of SMEs was determined in terms of business performance using measures such as profitability, growth, market share, return on investment, number of employees and product lines (Radipere and Dhliwayo, 2014). To establish success, we used convenience sampling as an initial sampling approach to identify known and accessible foreign-owned SMEs to establish how long they have been operational and to find out if they consider themselves as successful in their business ventures. Furthermore, the initial 


\section{ENTREPRENEURSHIP AND SUSTAINABILITY ISSUES}

ISSN 2345-0282 (online) http://jssidoi.org/jesi/ 2021 Volume 9 Number 1 (September)

http://doi.org/10.9770/jesi.2021.9.1(38)

questions also sought to determine the SMEs' number of employees, level of profitability and the variety of their product lines. This use of initial sampling technique was informed by Charmaz (2014: 197) who advised that "initial sampling in grounded theory gets you started, theoretical sampling guides where you go".

Following these criteria, the initial sample of six (6) successful foreign-owned SME owners were interviewed using the initial interview guide which comprises specific but open-ended questions on the value propositions of successful foreign-owned SMEs. As the interviews continued into the subsequent phases, the initial interview guide evolved when new questions were added, while some questions were reviewed, amended or removed to focus on the emergent themes and categories of data. Each interview lasted from between 45 to 60 minutes per session.

Subsequent sampling used a combination of snowball sampling and theoretical sampling techniques. Using snowball sampling, the initial sample provided leads to other successful foreign-owned SMEs known to them. Theoretical sampling involved starting with the initial data set obtained from the original sample to construct tentative ideas about the data and then examining these ideas through further empirical enquiry (Charmaz, 2014). Thus, theoretical sampling involves moving between data collection and data analysis throughout the research. Early data and codes raised unanswered questions. Similarly, early categories were suggestive but not yet definitive. Therefore, further data collection refined them and new insights from which to view data led to fresh conceptual directions. Several rounds of interviews continued until theoretical saturation was achieved. Theoretical saturation relates to the point when emerging concepts have been fully explored and no new theoretical insights are being generated (Charmaz, 2014). During this process, the researcher constantly returned to individual participants, checked the initial assumptions and collected more data until theoretical saturation was reached. According to Straus and Corbin (2008), theoretical saturation is reached when there is no new or relevant data emerging about a category that has been well developed in terms of its properties and dimensions and, lastly, when the relationships among categories are well established and validated. In this study, theoretical saturation was reached after interviewing forty-two (42) successful foreign-owned SMEs.

We used NVIVO 11 for storing, managing, and analyzing data. All audio recorded interviews were transcribed into text format after every interview. With each interview, concurrent data collection and data analysis were conducted until theoretical saturation was reached. The data analysis involved the use of open coding techniques (breaking down, examining, comparing, conceptualization and categorization of data). This process was followed by axial coding techniques procedures in which data was put together in new ways after open coding. Lastly, selective coding procedures of selecting the core categories, systematically relating it to other categories, validating relationships and filling in categories that need further refinement and development (Bryman and Bell, 2014). Throughout the whole process, constant comparisons of emerging categories and concepts were conducted to maintain a close connection between concepts and categories (Straus and Corbin, 2008). NVIVO 11 software enabled the management of large 'chunks' of data, coding and qualitative data analysis.

To ensure trustworthiness (validity and reliability), we used the five criteria of trustworthiness measures proposed by Wallendorf and Belk (1989), namely credibility, transferability, dependability, confirmability and integrity. In particular, we used member checks in several rounds of interviews to also validate previously made assertions and to ensure the overall trustworthiness of our findings. The following section presents the findings of this study.

\section{Findings}

The findings presented in this paper emerged from the primary questions that sought to identify the value propositions of successful foreign-owned SMEs. Specifically, the questions related to the unique set of benefits offered by the foreign-owned businesses to their customers, as well as to how they offer these benefits. 


\subsection{Participant background Information}

Forty-two (42) successful foreign-owned SMEs were interviewed in multiple rounds of interviews. These participants were from different business types including Retail, Business, Legal Consultancy, Information Technology and Electronics, Construction and Maintenance Services, Cosmetics and Beauty Services and Hospitality Services. Table 1 shows a summary of the participants' background information in terms of country of origin, gender, the average number of years in business and the average number of employees.

Table 1. Participants' Background Information

\begin{tabular}{|c|c|c|c|c|c|}
\hline Country of origin & $\begin{array}{l}\text { Number of } \\
\text { participants }\end{array}$ & Number of Males & $\begin{array}{c}\text { Number of } \\
\text { Females }\end{array}$ & $\begin{array}{c}\text { Average Age in } \\
\text { Business }\end{array}$ & $\begin{array}{c}\text { Average Number } \\
\text { of employees }\end{array}$ \\
\hline Bangladesh & 2 & 2 & 0 & 16 & 35 \\
\hline Ethiopia & 2 & 2 & 0 & 9 & 4 \\
\hline Ghana & 3 & 2 & 1 & 9 & 9 \\
\hline India & 2 & 2 & 0 & 13 & 6 \\
\hline Liberia & 1 & 1 & 0 & 10 & 32 \\
\hline Malawi & 2 & 1 & 1 & 5 & 15 \\
\hline Nigeria & 7 & 5 & 2 & 8 & 6 \\
\hline Pakistan & 2 & 2 & 0 & 10 & 4 \\
\hline Portugal & 1 & 1 & 0 & 14 & 35 \\
\hline Zambia & 6 & 5 & 1 & 6 & 6 \\
\hline Zimbabwe & 14 & 9 & 5 & 8 & 15 \\
\hline Total & 42 & 32 & 10 & & \\
\hline \multirow{3}{*}{\multicolumn{4}{|c|}{$\begin{array}{r}\text { Combined Mean } \\
\text { Min } \\
\text { Max }\end{array}$}} & 9 & 12 \\
\hline & & & & 5 & 4 \\
\hline & & & & 16 & 35 \\
\hline
\end{tabular}

Participants came from eleven (11) different countries. The largest number of participants were from Zimbabwe (14), followed by Nigeria (7), Zambia (6) and Ghana (3). Bangladesh, Ethiopia, India and Pakistan were represented by 2 participants each while one (1) participant was from Portugal. One participant (the owner) from each SME was interviewed.

Thirty-two (32) of the participants were males and ten (10) were females. Their combined average number of years in business was nine (9) years, with a minimum of 5 years and a maximum of 16 years. The combined average number of employees was twelve (12), with a minimum of four (4) employees and a maximum of thirtyfive (35) employees. The National Small Business Act, 106 of 1996 classifies micro enterprises as businesses with less than 5 employees. The majority of businesses used in this study had more than 5 employees (except for a few selected businesses which met other criteria such as the number of years in business and/or annual turnover as reported by participants) thus, this the study was not only concerned with micro enterprises. We acknowledge, however, that the majority of businesses used ranged from very small (10 - 20 employees) to small (less than 50 employees) with a few medium sized (more than 50 employees) hence a low mean number of employees of 12 . The following section presents the results of open coding. 


\subsection{Open Coding}

The first step of data analysis used open coding techniques in which relevant terms, phrases, statements and observations were coded. Table 2 shows a list of open codes identified during the open coding process.

Table 2. List of Value Propositions Open Codes

\begin{tabular}{lll}
\hline Empathizing with customers & Unique styles & Discounts \\
Finding something within & Addressing a need in society & Complementary services \\
Not expensive & Training own staff for good service & Customised services \\
Good service & Repeat business. & No short cuts \\
Motivate clients & Quality products & Proper products \\
Providing access & Not copying others & Building trust \\
Closer to the people & Unique service & Diversity \\
Foreign clients & Loyal staff for good service & Connections \\
Available online & Flexible to customers & Quality of service \\
Marginalised markets & Home-cooked meals & Timeous delivery \\
Meaningful contribution & Quality service & Access to goods \\
Lower prices & Few service providers & Providing the service as and when \\
Perfect work & Catering to diverse customers & it is required. \\
Well known by customers & Flexible payment terms & Going to clients' homes \\
Be yourself / authenticity & Feeling at home & Proximity to clients \\
Predominately in townships and rural areas & Affordability & Being more available \\
Something unique & Competitiveness & Being there \\
Organic food & Going an extra mile & \\
Trust relationship & Understanding clients' needs & \\
& Diversity of offerings & \\
\hline
\end{tabular}

\subsection{Axial Coding}

Following the open coding processes, axial coding was applied to the data to build categories and their properties. In total, $92^{\text {nd }}$ order themes and three aggregate dimensions were developed, as shown in Figure 1. The aggregate dimensions that emerged from our analysis are customer interaction values, product/service values and business process values. These dimensions are discussed in the following subsections.

\subsubsection{Customer interaction Values}

The customer interaction value relates to the value that is derived from the manner in which the business interacts with its customers. In this category, successful foreign-owned SMEs expressed their accessibility, ability to serve marginalized customer groups, and their appeal to diverse customers as the basis for their customer interaction values. These issues are discussed in the following subsections.

\section{Accessibility}

Accessibility was cited by 20 participants as one of the value propositions who indicated that they provided access to goods and services that would otherwise not be available to some sections of the population. Participant 1 remarked that his SME "assists in making legal and other services available... to almost everyone". Similar sentiments were echoed by Participant 15 who conveyed that "it's [about] giving people access to goods they would otherwise not [be able to] afford'.

The concept of accessibility was also evident in terms of the location of the majority of the foreign-owned SMEs. Most businesses were located within easy reach of their target customers. This observation was confirmed by Participant 6 who revealed that "in the catering business you have to make sure that you are located at a place 


\section{ENTREPRENEURSHIP AND SUSTAINABILITY ISSUES}

ISSN 2345-0282 (online) http://jssidoi.org/jesi/ 2021 Volume 9 Number 1 (September) http://doi.org/10.9770/jesi.2021.9.1(38)

where you have access to all the people who are working, and everyone else". There was also an expression of a conscious selection of locations that were suitable for the type of business. Most foreign-owned SMEs were located in townships, downtown market areas and rural areas. Participant 24, who operated a chain of butchery and general merchandise shops, confirmed this observation, stating that "we are predominately in the locations, in the rural areas, in the homesteads". Other facets of accessibility were in terms of provision of delivery services and online business presence.

Also related to the notion of location is the flexibility of the participants' SMEs to offer services according to the needs of customers. The business owners in this study who were involved in general merchandise retail and electronics services, especially those in the rural areas and outskirts, indicated that they operated their businesses outside normal working hours.

In the consulting industry, being available when needed by a client is a common concept, also pointing to flexibility. Participant 20 emphasized this notion when he asserted "I'm available and I'm letting my clients and networks know that I'm fully available." Participant 16 expressed similar sentiments: "I am willing to serve you. I started by making myself available to existing companies." A closer look at Participant 16's affirmation of willingness to serve customers was a clear indication of answering customers' needs. Participant 9 echoed that the "customer is like a god, that's my motto". Similar assertions were made by 19 other participants.

\section{Serving marginalized customer groups}

Also related to the concept of serving diverse customers was that of serving marginalized customer groups. This category was expressed by 4 participants in this study. Here, the successful foreign-owned SME owners indicated that they chose their business locations carefully to ensure that they reached the unserved and marginalized market segment. To illustrate this, Participant 22 indicated they normally served "marginalized markets in the rural communities". Similar sentiments were echoed by Participant 24 who related that "we are predominately in the locations [townships], in the rural areas, in the homesteads". This concept was also found to be related to the notion of accessibility.

\section{Diversity of clients and goods}

Other participants mentioned the diversity of clients and goods they served as part of their value proposition. Four (4) participants in this study expressed this view. This notion was further reinforced by the participants in the catering business who indicated that they offered a variety of menus to cater to the diversity of their clients' needs and backgrounds. This approach was seen as beneficial to SMEs because it increased their market base.

\subsubsection{Product/Service Values}

The product/service values relate to the specific aspects of the product or service from which the customer derives value. Among the successful foreign-owned SMEs interviewed in this study, affordability, quality and uniqueness emerged as among the key product/service values in their businesses. These are discussed in the following subsections.

\section{Affordability}

Another component of the value proposition of foreign-owned SMEs relates to the affordability of their goods and services. This factor was reinforced by 28 participants. Participant 13 highlighted that their pricing was structured in such a way that it suited their customers' buying power. Participant 13 advised that "where the buying power is not that strong, irrespective of the quality, you have to think of a very reasonable mark up so that it can be affordable for your client". Similar sentiments were expressed by Participant 17 who advised that "make sure that you don't go for the kill. Don't try to [put] your price too high". Participant 30 also mentioned that "we are way cheaper than established retailers". 
ENTREPRENEURSHIP AND SUSTAINABILITY ISSUES

ISSN 2345-0282 (online) http://jssidoi.org/jesi/ 2021 Volume 9 Number 1 (September)

http://doi.org/10.9770/jesi.2021.9.1(38)

$1^{\text {st }}$ Order Codes

$\underline{2^{\text {nd }}}$ Order Themes

Aggregate Dimension

\section{- Location}

- Flexible to customers

- Deliver to customers

- Being available

- Available online

- Providing access

- Go to clients' home

- Proximity to clients

- Closer to people

- Foreign clients

- Predominately in townships

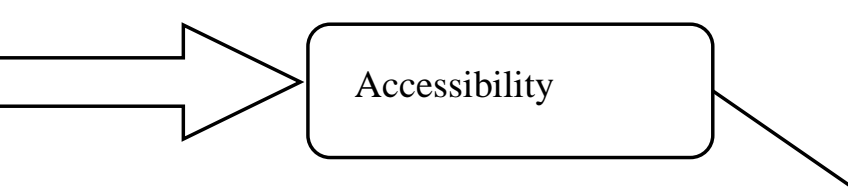

- Cater for diverse customers

- Diversity of offerings

- Diversity

- Lower prices

- Discounts

- Payment terms

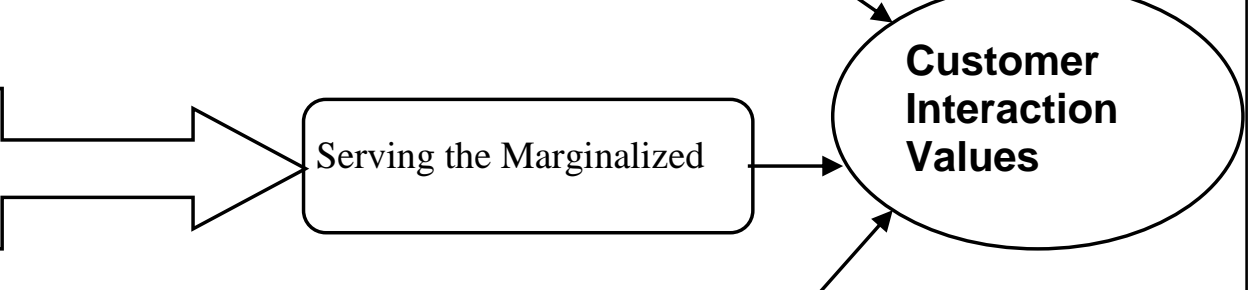

Few service providers

-Home-cooked meals

-Organic products

-Something unique
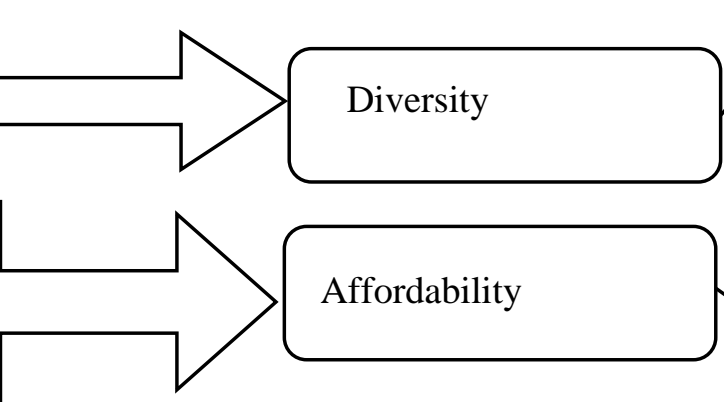

Affordability

- Reliability

- Quality service

- Feel at home

- Competitive

- Empathising with customers

- Good service

- Motivate clients

- Well known by customers

- Understanding clients' needs

- Be yourself

- Not copying others

- Authentic

-No short cuts

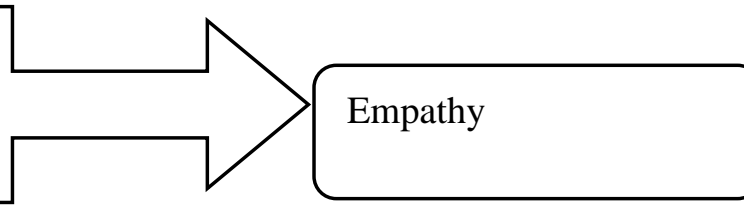

Quality

Product Uniqueness

Product/Service

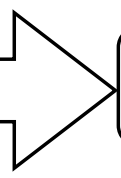

Prodict Uniquess

Empathy

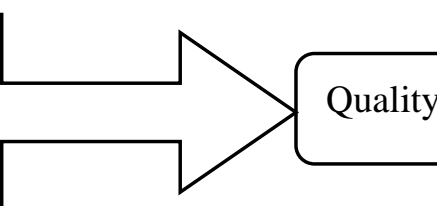

Envy

- Reliability 


\section{ENTREPRENEURSHIP AND SUSTAINABILITY ISSUES}

ISSN 2345-0282 (online) http://jssidoi.org/jesi/ 2021 Volume 9 Number 1 (September)

http://doi.org/10.9770/jesi.2021.9.1(38)

Figure 1. Data Structure, Customer Interaction Values, Product Service Values, and Business Process Values

In addition to the participants' accounts, the researcher's first-hand experiences and comparison of prices for similar products confirmed that the majority of products offered by foreign-owned SMEs were cheaper than those offered by large retailers who were operating in the shopping malls and city centres. Therefore, the affordable prices offered by foreign-owned SMEs appeared to be one of their strong value propositions.

Linked to the concepts of affordability, is the notion of payment terms. This was mentioned by ten (10) of the participants who indicated that one of the unique benefits they offered to their trusted customers was flexible payment terms. Participant 17, when talking about dealing with clients who could not pay their fees upfront, relayed that "what normally works is a form a credit system". Participant 7, an engineering consultant, also indicated this benefit when she explained that:

Unlike other private consultants who need their money upfront, I am flexible to say, you know, I understand this project is for the government, you can pay me something now but when you get paid you can pay me the rest. So usually, it's like $20 \%$ upfront just for me to afford to do the job.

Similar assertions were made by other SMEs who operated in general merchandise retail, hair and beauty, and catering.

\section{Quality Products/Services}

Another concept that came out strongly was that of quality, which was mentioned in 42 (all) accounts. This consensus means that participants viewed quality in different terms, whereby, one participant could describe it in more than one word or mentioned quality several times in their accounts. Participants indicated that they prioritized offering high-quality goods and services to their customers. Participant 12 summed up this concept, maintaining that "our values are excellence. So, we want to get someone who is going to do a good job and deliver so that that can create more opportunities". This assertion also implies that with high-quality services come more business opportunities, hence the desire to offer high-quality goods and services all the time. All the participants interviewed demonstrated their commitment to high-quality goods and services to their customers.

Another facet of the value proposition of foreign-owned SMEs emerged in the form of the good service that they offer. This concept was evident in 30 accounts of the participants interviewed. Participants expressed that it was through the good service that they offered their clients that they were able to secure repeat purchases. Participant 16 explained that "delivering good services makes them [customers] come to you all the time". The concept of good service also appeared in the form of an 'extra mile' to ensure that the client received a satisfying service. Participant 14 stated: "If your client says 'polish my shoe', then polish it, it will not kill you, provided that you are getting your money, you are getting your services." This also confirms the emphasis placed on customer satisfaction.

\section{Offering unique products}

The business owners also expressed their value proposition in terms of offering unique products. This concept was found in 29 accounts of the interviewed participants. The uniqueness of the products ranged from homecooked meals, organic products, unique service or style offerings, imported products and unique medical benefits. Participant 19 relayed that their value proposition was based on "bringing in a new product, new ways of doing things". The same sentiments were echoed by several other participants. 


\section{ENTREPRENEURSHIP AND SUSTAINABILITY ISSUES}

ISSN 2345-0282 (online) http://jssidoi.org/jesi/

2021 Volume 9 Number 1 (September)

http://doi.org/10.9770/jesi.2021.9.1(38)

\subsubsection{Business Process Values}

The business values relate to the value proposition that arises from the day to interactions and processes of the business. In successful foreign-owned SMEs, we found that business process values arise from understanding clients' needs, authenticity in business operations and overall reliability.

\section{Understanding clients}

One of the key sources of business process values that emerged from our study related to the concept of understanding clients. This notion emerged in 42 accounts. Participants expressed that by understanding clients' needs, they can deliver customized products or services that satisfy their clients. For example, Participant 14 stated the following: "I listen to people's needs and work from there." Similar sentiments were expressed by Participant 16, who mentioned that understanding clients involved understanding their needs and the challenges that they expected the business to address. Participant 19 added that "we do background research on the customer, so we don't go in blind, because of our unique selling points, we try to say, 'What can we do for you?'. These statements confirm a consumer-centric approach to business, in which the actions of the business towards addressing the customer's problem are informed and guided by the customer's specific needs.

\section{Authenticity and Honesty}

Authenticity also emerged as another value proposition of foreign-owned SMEs. Although this concept was not explicitly spelled out by most participants, its presence was strongly expressed in 6 accounts. Participant 13 indicated that "[my] unique way of doing my business is to just be, be myself... as real as possible, so that my clients will have that confidence in me". Similar sentiments were expressed by Participant 14 who indicated that "I want to be as authentic as possible". Although other participants did not explicitly express the concept of authenticity, their genuine interest in the subject matter could be seen through their facial expressions and tone of voice. In one of the memos written while waiting to interview Participant 27, the following was noted:

The expressions of this SME owner as he speaks to his clients demonstrate a keen interest in his work and show noticeable originality in his conduct. I overheard him telling the client that

he could not fix the customer's broken cell phone and advised his client to go to the manufacturer since the product was still under a warranty. This gesture is a clear indication of authenticity and honesty in business by this specific business owner.

\section{A memo dated 28 September 2018, Gauteng}

Participants stressed the importance of honesty and integrity when providing goods and services to clients. Although this concept was expressed in only nine accounts, it was also confirmed through personal observations. The business owners showed a remarkable level of honesty and integrity in their professional conduct. Participant 8 who runs a carwash business, confirmed this when he said: 
ENTREPRENEURSHIP AND SUSTAINABILITY ISSUES

ISSN 2345-0282 (online) http://jssidoi.org/jesi/

2021 Volume 9 Number 1 (September)

http://doi.org/10.9770/jesi.2021.9.1(38)

You know, honesty, that is a very important thing, whenever a customer comes and within

their cars, I need to try my level best to check with the guy that they should not pick up

anything from the cars.

Similar sentiments were expressed by Participant 16, who owns a training consultancy business, who when asked about how he obtained a government tender narrated his experience with one of the government officers who attempted to solicit a bribe. He concluded his narrative by saying: "...out of integrity, this is not what we do, we don't offer gifts or anything". The participants emphasized that with honesty and integrity comes trust, and it is from the trust relationship that they build with their clients that they can create long-term business relationships and benefit from repeat purchases.

\section{Reliability}

Participants pointed to their timeous delivery and reliability as another source of their value proposition. This fact was expressed in 14 accounts of the interviewed participants across all business sectors, but the importance of timeous delivery was stated most strongly in the catering business. Participant 11, who ran a catering business, stressed that "we make sure that we are very punctual ... The maximum time we expect our customers to wait is just 10 minutes". Participant 27, who operated an electronics repair shop, provided the following example: "If you bring your laptop or your phone... I'll fix it now, I'll give it to you, and you go with it". The emphasis on timeous delivery was also confirmed by the researcher's observations while waiting to interview Participant 11 in her restaurant.

\subsection{Selective Coding and Constant Comparative Analysis}

The final step in the analysis of data involved the management of concepts and categories based on node hierarchies. In NVIVO, nodes were structured in a branching hierarchical system with categories and subcategories grouped to form node hierarchies, also known as tree nodes (Hutchison, Johnston and Breckon, 2010). This process was conducted to address conceptually related categories that were found scattered in our lists. Moreover, categories that initially seemed distinct but found to be related were combined into one group. We then used coding stripes to analyse the possible relationship between the concepts and categories. An analysis of coding stripes showed relationships between all the value proposition concepts and categories. These coding stripes enabled us to view segments of text as well as the additional nodes that are coded to that particular selection of text. Consequently, coding stripes enabled us to compare categories and concepts. Using the guidelines provided in Hutchison et al. (2010), we, therefore, used coding stripes to provide a visual overview of the possible relationships between concepts.

Figure 2 is an illustration of the analysis of the coding stripes on NVIVO 11. 
ISSN 2345-0282 (online) http://jssidoi.org/jesi/ 2021 Volume 9 Number 1 (September) http://doi.org/10.9770/jesi.2021.9.1(38)

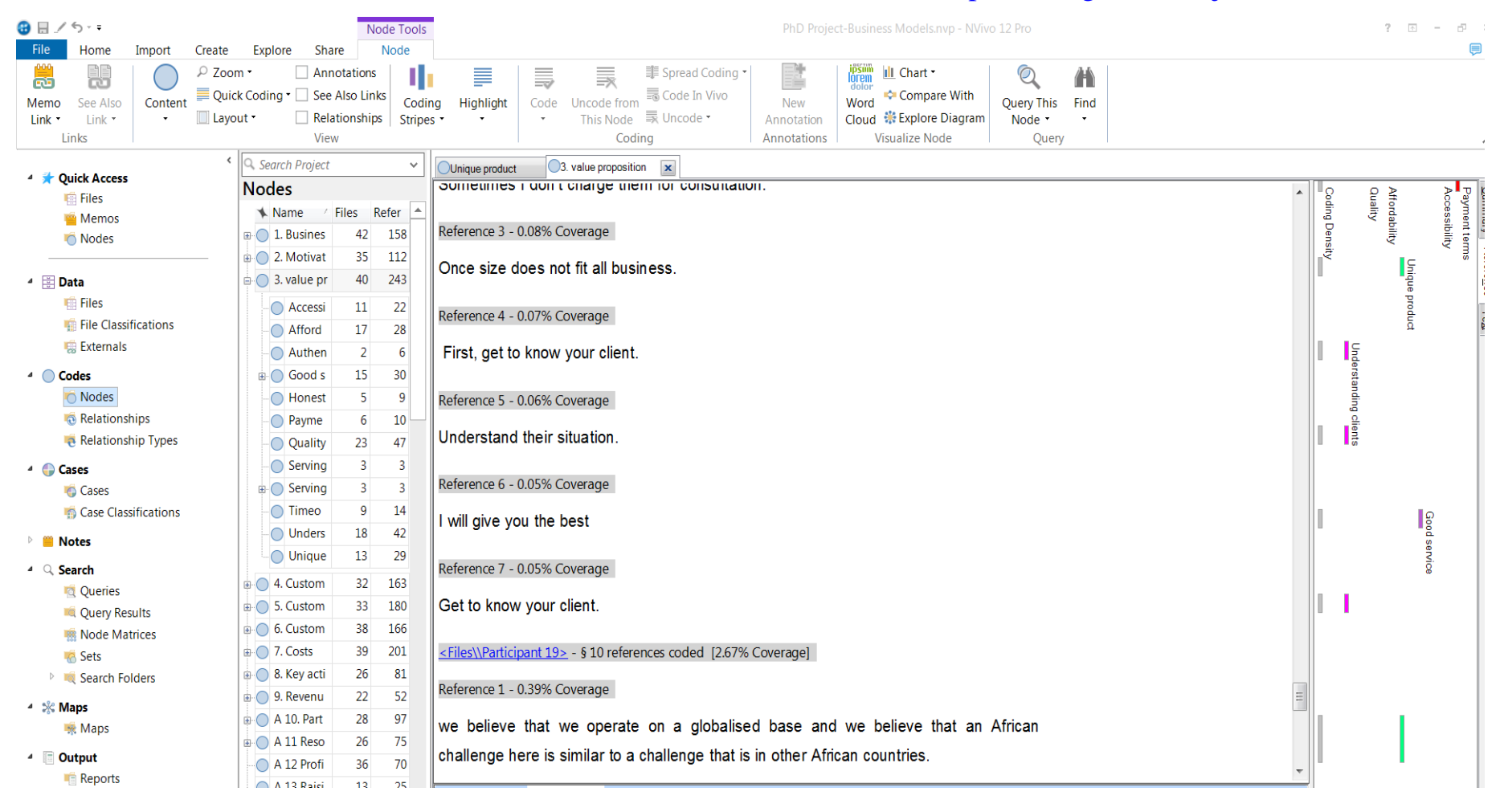

Figure 2. NVIVO12 Screenshot: Results of Node Value Propositions with Coding Stripes

The relationship between all the emergent value propositions is an indication that successful foreign-owned SMEs do not only use a single concept but rather combine various concepts in constructing their value proposition. Thus, the emergent value propositions were found to complement each other. This combination of concepts enables the participating SMEs to appeal to a variety of customer segments and allows the business to operate within a sustainable VPM. Furthermore, an analysis of the coding stripe and constant comparative techniques gave rise to the VPM constructed in this study. By grouping the various dimensions in our analysis, based on the observed relationships using coding stripes, (as illustrated in Figure 2), three value themes were developed, namely, product/service values, customer interaction values, and business process. These values were used as a basis for our VPM framework as shown in Table 3. The VPM framework provides a useful and simplified visualization of the observed relationships, together with operationalized definitions of each theme.

Table 3. A VPM Framework for SMEs

\begin{tabular}{|c|c|c|}
\hline Values & Operational Definition & Dimensions \\
\hline \multirow[t]{4}{*}{ Product/Service } & \multirow[t]{4}{*}{ Values attached to the product or service offering. } & Product/Service quality \\
\hline & & Product/Service Uniqueness \\
\hline & & Affordability \\
\hline & & Good service \\
\hline \multirow[t]{4}{*}{ Customer Interaction } & \multirow{4}{*}{$\begin{array}{l}\text { Values attached or related to interactions and } \\
\text { contact with customers }\end{array}$} & Accessibility \\
\hline & & Serving the Marginalised \\
\hline & & Serving Diverse Customers \\
\hline & & Understanding Clients \\
\hline \multirow[t]{3}{*}{ Business Process } & \multirow[t]{3}{*}{ Values attached to business processes. } & Authenticity and honesty \\
\hline & & Timeous Delivery \\
\hline & & Payment Terms \\
\hline
\end{tabular}


The VPM framework provided in Table 3 above identifies the three core values, provides operationalized definitions of each of the core values, as well as identifying the key dimensions of each of the three values. It is important to note that the dimensions presented in the VPM framework are not exhaustive but are a simple illustration of the dimensions observed within the limits of the empirical investigations of this study. It is also important to note that in our investigations and analysis, it was not possible to formulate a universal VPM. Variations among successful foreign-owned SMEs and other businesses, therefore, are unavoidable. To address this, we further developed a typology of value proposition to serve as "a yardstick, an abstraction, and simplification" (Elo, 2016:132,) of successful value proposition combinations based on the line of business.

Table 4 below shows a typology of successful value proposition combinations identified in this study. Although different combinations are notable among different lines of business, there are some common value dimensions across all business lines. In terms of the product/service values, product/service quality, affordability, and good service are found in all lines of businesses investigated in this research study. Commonalities are also notable in customer interaction values in which the dimension of understanding clients is expressed in all lines of businesses. In the business process values, the dimension on payment terms is found in all lines of businesses. This analysis, therefore, provides a yardstick and simplification of successful value proposition combinations, classified according to the line of business. While slight differences among businesses within the same line of business were noted, the differences were not sufficiently significant for them to be presented on a case-by-case basis. Furthermore, acknowledging that the dimensions observed in our study are limited to our investigation of selected successful foreign-owned SMEs, future studies may identify and include more dimensions to the VPM.

Table 4. Typology of the value proposition of successful foreign-owned SMEs based on line of business

\begin{tabular}{|c|c|c|c|c|c|c|}
\hline Line of Business & Retail Business & $\begin{array}{l}\text { Legal } \\
\text { Consultancy }\end{array}$ & $\begin{array}{l}\text { Information } \\
\text { Technology } \\
\text { and } \\
\text { Electronics }\end{array}$ & $\begin{array}{l}\text { Construction } \\
\text { and } \\
\text { Maintenance } \\
\text { Services }\end{array}$ & $\begin{array}{l}\text { Cosmetics and } \\
\text { Beauty } \\
\text { Services }\end{array}$ & $\begin{array}{l}\text { Hospitality } \\
\text { Services }\end{array}$ \\
\hline \multirow[t]{4}{*}{$\begin{array}{l}\text { Product/Service } \\
\text { Values }\end{array}$} & $\begin{array}{l}\text { Product/Service } \\
\text { quality }\end{array}$ & $\begin{array}{l}\text { Product/Service } \\
\text { quality }\end{array}$ & $\begin{array}{l}\text { Product/Service } \\
\text { quality }\end{array}$ & $\begin{array}{l}\text { Product/Service } \\
\text { quality }\end{array}$ & $\begin{array}{l}\text { Product/Service } \\
\text { quality }\end{array}$ & $\begin{array}{l}\text { Product/Service } \\
\text { quality }\end{array}$ \\
\hline & Affordability & Affordability & $\begin{array}{l}\text { Product/Service } \\
\text { uniqueness }\end{array}$ & $\begin{array}{l}\text { Product/Service } \\
\text { uniqueness }\end{array}$ & $\begin{array}{l}\text { Product/Service } \\
\text { uniqueness }\end{array}$ & $\begin{array}{l}\text { Product/Service } \\
\text { uniqueness }\end{array}$ \\
\hline & Good service & Good service & Affordability & Affordability & Affordability & Affordability \\
\hline & & & Good service & Good service & Good service & Good service \\
\hline \multirow{4}{*}{$\begin{array}{l}\text { Customer } \\
\text { Interaction } \\
\text { Values }\end{array}$} & Accessibility & $\begin{array}{l}\text { Serving the } \\
\text { marginalised }\end{array}$ & Accessibility & $\begin{array}{l}\text { Understanding } \\
\text { clients }\end{array}$ & Accessibility & Accessibility \\
\hline & $\begin{array}{l}\text { Serving the } \\
\text { marginalised }\end{array}$ & $\begin{array}{l}\text { Serving diverse } \\
\text { Customers }\end{array}$ & $\begin{array}{l}\text { Serving the } \\
\text { marginalised }\end{array}$ & & $\begin{array}{l}\text { Serving the } \\
\text { marginalised }\end{array}$ & $\begin{array}{l}\text { Serving diverse } \\
\text { customers }\end{array}$ \\
\hline & $\begin{array}{l}\text { Serving diverse } \\
\text { customers }\end{array}$ & $\begin{array}{l}\text { Understanding } \\
\text { clients }\end{array}$ & $\begin{array}{l}\text { Serving diverse } \\
\text { customers }\end{array}$ & & $\begin{array}{l}\text { Serving diverse } \\
\text { customers }\end{array}$ & $\begin{array}{l}\text { Understanding } \\
\text { clients }\end{array}$ \\
\hline & $\begin{array}{l}\text { Understanding } \\
\text { clients }\end{array}$ & & $\begin{array}{l}\text { Understanding } \\
\text { clients }\end{array}$ & & $\begin{array}{l}\text { Understanding } \\
\text { clients }\end{array}$ & \\
\hline \multirow[t]{3}{*}{$\begin{array}{l}\text { Business Process } \\
\text { Values }\end{array}$} & Payment terms & $\begin{array}{l}\text { Authenticity and } \\
\text { honesty }\end{array}$ & $\begin{array}{l}\text { Authenticity and } \\
\text { honesty }\end{array}$ & $\begin{array}{l}\text { Timeous } \\
\text { delivery }\end{array}$ & $\begin{array}{l}\text { Authenticity and } \\
\text { honesty }\end{array}$ & $\begin{array}{l}\text { Authenticity and } \\
\text { honesty }\end{array}$ \\
\hline & & $\begin{array}{l}\text { Timeous } \\
\text { delivery }\end{array}$ & $\begin{array}{l}\text { Timeous } \\
\text { delivery }\end{array}$ & Payment terms & $\begin{array}{l}\text { Timeous } \\
\text { delivery }\end{array}$ & $\begin{array}{l}\text { Timeous } \\
\text { delivery }\end{array}$ \\
\hline & & Payment terms & Payment terms & & Payment terms & Payment terms \\
\hline
\end{tabular}




\section{ENTREPRENEURSHIP AND SUSTAINABILITY ISSUES}

ISSN 2345-0282 (online) http://jssidoi.org/jesi/

2021 Volume 9 Number 1 (September)

http://doi.org/10.9770/jesi.2021.9.1(38)

\section{Discussions}

Our study set out to identify the value propositions of successful foreign-owned SMEs to use these value propositions to inform the broad development, sustainability, and growth of the SME sector in South Africa and beyond. Understanding the value propositions of successful foreign-owned SMEs is a key step towards crosscultural and cross-border knowledge transfer and diffusion and, thus, a move towards international entrepreneurship. This study could provide new insights into the initiatives aimed at addressing the high failure rate among SMEs in South Africa (Asah, Louw \& Williams, 2020; Schachtebeck, Groenewald \& Nieuwenhuizen, 2019).

While many studies (for example see Moos \& Sambo, 2018; Musara \& Fatoki, 2011; Pillay, 2019; Schachtebeck et al., 2019; Wentzel, Smallwood \& Emuze, 2016) sought to provide solutions to the high failure rates of SMEs in South Africa from a native-owned SMEs perspective. Our study set out from the premise that, potentially, new insights could be drawn from studying the business models of successful foreign-owned SMEs. This premise is not unique to our study. Extant global literature (for example see Choudhury \& Kim, 2018; Ling, Yen, \& Yen, 2016; Makkonen, Williams, Weidenfeld \& Kaisto, 2018) based their investigations on similar premises and found that in most cases foreign-owned businesses are a reservoir of unexplored knowledge that could benefit nativeowned businesses.

Although some of the value proposition dimensions revealed in this paper have been noted in other contexts, for example as success factors from a marketing perspective (see, Alfoqahaa, 2018; Gupta \& Mirchandani, 2018; Moeuf, 2020) and in business model literature (see, Osterwalder, et al., 2014)), this paper still contributes to the broad range of existing literature by providing insights from successful foreign-owned SMEs. This endowment is important in advancing the theoretical discourse on the subject matter by offering insights from an unexplored context of successful foreign-owned SMEs.

While successful foreign-owned SMEs also employ commonly known value propositions, this study identified some of their unique value propositions. The commonly used value propositions are in the form of product/service values that have been identified in the existing literature, for example in the findings of Osterwalder, Pigneur, Bernarda \& Smith, (2014). In addition to commonly adopted value propositions, successful foreign-owned SMEs include customer interaction and business process values in their VPM.

Both customer interaction and business process values have been observed to be key facilitators of the co-creation of value for customers. Previous studies such as Vorbach, Müller, and Poandl (2019) as well as Quero and Ventura (2019) attest to the co-creation potential that arises from our observed dimensions of customer interaction values, i.e understanding clients, authenticity, and reliability. The focus on customer interaction values follows the service-dominant (S-D) logic which emphasizes that value is co-created by customers and is the outcome of the activities and interactions in which resources are integrated and utilized for mutual benefits (Skålén, et al., 2014). In the study entitled "Dynamics of value propositions: Insights from a Service-Dominant Logic", Kowalkowski (2011) expressed the importance of customer interaction as being among the guiding principles for designing market offerings, strategic communication of the firm's value proposition, and development of competitive advantages. In addition, customer interaction values enable the discovery of opportunities for value creation that would otherwise be constrained by the traditional goods-dominant logic (Kowalkowski, 2011; Skålén, et al., 2014). Our research findings confirm those of Zaborek \& Mazur (2019) who in their study of value co-creation in Polish Manufacturing and Service SMEs revealed that "Service firms benefit from engaging in dialogue with customers, while manufacturers show the positive influences of enhanced interaction and more choice options". Thus, the inclusion of the customer interaction values enables the businesses to understand their customers' needs 


\section{ENTREPRENEURSHIP AND SUSTAINABILITY ISSUES}

ISSN 2345-0282 (online) http://jssidoi.org/jesi/

2021 Volume 9 Number 1 (September)

http://doi.org/10.9770/jesi.2021.9.1(38)

and, as a result, engage in the co-creation of value propositions with their customers which, in turn, engenders an unfettered source of competitive advantages.

Similarly, business process management, which is akin to our business process values, was noted to facilitate the co-creation of customer value (Noci, 2019; To, Chau \& Kan, 2020). The business process values provide an anchorage to the customer interaction values in which business processes support the holistic value creation practices of the business. Supporting this view, previous studies such as those of Ebert (2016) and Kirchmer (2017) emphasised that SMEs need value-driven business process management to succeed. According to Kirchmer (2017) value-driven business process management provides insights into the most critical areas that the firm should improve upon to unlock untapped value. This view espouses that the business process values observed in this study are important for success.

Both customer interaction and business process values require that SMEs work closely with their customers for the co-creation of value propositions. This situation implies the need for SMEs to forge relationships with their customers. Considering the South African SME context, the long history of SMEs' failure rate due to challenges such as a failure to access markets (Cant, 2012; van Scheers \& Mmatli, 2019), access to finance (Elizabeth, Popoola \& Popoola, 2020; Musara \& Fatoki, 2011), among others can be addressed through the introduction of mutually beneficial customer interaction and business process values. This perspective is supported by Chen, Liu, and Wan (2020) who concluded that SMEs would find it worthwhile to focus their attention on maintaining strong relationships, based on trust and commitment, with their customers. This fact is especially important for SMEs in South Africa primarily because Hare \& Walwyn, (2019) observed a lack of trust as being among the inhibitors of access to markets for SMEs in South Africa. Thus, the application of customer interaction and business process values are important in this context.

The VPM framework addresses the four core customer values proposed by Fernandes et al. (2019), namely functional, emotional, change of life, and social impact. The functional values are synonymous with product/service values in the VPM framework, while the emotional, change of life, and social impact values relate to customer interaction values. These business process values are unique to this study and are equally valuable for the success of businesses. For example, authenticity means that the business exercises truth throughout its business processes and operations within its resource constraints.

Extant literature (Baldassarre, Calabretta, Bocken \& Jaskiewicz, 2017; Katz, 2010; Payne, Frow \& Eggert, 2017) has focused extensively on product/service values with little regard for customer interaction and business process values. The inclusion of customer interaction and business process values in the VPM provides a holistic view of the value proposition concepts. The VPM frameworks present a holistic view of what values customers receive (product/service values), how customers interact with the business and participate in the co-creation of values (customer interaction values) as well as how the business creates and delivers the values to customers (business process values). This holistic view of the value proposition provides SMEs with much-needed opportunities for growth and ultimate success.

\section{Practical value of the findings}

The insight arising from the findings of this paper is that successful foreign-owned SMEs have a VPM that includes product/service values, customer interactions as well as business process values has some merit. Understanding such a VPM is not only important for the success of SMEs but also provides opportunities for cocreation of value proposition between the SMEs and their customers. While this study focussed on successful foreign-owned SMEs due to their distinctiveness within the SME sector in South Africa, in having succeeded regardless of their having experienced additional business challenges, the findings of this study could be applied to native-owned SMEs. This can inform policy aimed at growing the SME sector in South Africa and abroad through cross-cultural and cross border transfer of business knowledge. 


\section{ENTREPRENEURSHIP AND SUSTAINABILITY ISSUES}

ISSN 2345-0282 (online) http://jssidoi.org/jesi/ 2021 Volume 9 Number 1 (September)

http://doi.org/10.9770/jesi.2021.9.1(38)

\section{Research Limitations and future research}

This study is based on a qualitative grounded theory investigation of selected successful foreign-owned SMEs in South Africa. However, the study provides a springboard for further studies on value propositions in the broader SME sector. In this regard, we are looking forward to three exciting research streams in the future. The first research stream could seek to expand the menu of the value proposition dimensions by exploring a variety of industries, including value propositions in successful locally owned businesses as well as value propositions in large organisations that may be adapted to the SME sector. The second research stream could explore quantitative methodologies to generate research instruments, validate, and increase the generalisability of the findings of the study. The third research stream could conduct longitudinal studies to test the effectiveness of a variety of VPMs in the SME sector. Thus, further development of the VPM concepts is undoubtedly imminent.

\section{References}

Abrahamsson, J., Vanyushyn, V. \& Boter, H. (2019). Organisational innovativeness of international new ventures: evidence from Swedish firms. European Journal of International Management, 13(4), 479-495. https://doi.org/10.1504/EJIM.2019.100792.

Alfoqahaa, S. (2018). Critical success factors of small and medium-sized enterprises in Palestine. Journal of Research in Marketing and Entrepreneurship, 20(2), 170-188. https://doi.org/10.1108/JRME-05-2016-0014.

Altman, E. I., Esentato, M. \& Sabato, G. (2020). Assessing the credit worthiness of Italian SMEs and mini-bond issuers. Global Finance Journal, 43, 1-11. https://doi.org/10.1016/j.gfj.2018.09.003

Amit, R. and Zott, C. (2012). Creating value through business model innovation. MIT Sloan Management Review, 53(3), 41-49. https://doi.org/10.4102/jef.v13i1.510

Arthur, P. (2020). SMEs, Industrialization and Disruptive Technologies in Africa: Enabling or Constraining?. In Disruptive Technologies, Innovation and Development in Africa (pp. 205-226). Palgrave Macmillan, Cham. https://doi.org/10.1007/978-3-030-40647-9_10.

Asah, F. T., Louw, L. \& Williams, J. (2020). The availability of credit from the formal financial sector to small and medium enterprises in South Africa. Journal of Economic and Financial Sciences, 13(1), 1-10. https://doi.org/10.4102/jef.v13i1.510.

Asongu, S. and Odhiambo, N. (2019). Doing business and inclusive human development in Sub-Saharan Africa. African Journal of Economic and Management Studies, 10(1), 2-16. https://doi.org/10.1108/AJEMS-05-2018-0132 .

Baldassarre, B., Calabretta, G., Bocken, N. M. P. \& Jaskiewicz, T. (2017). Bridging sustainable business model innovation and user-driven innovation: A process for sustainable value proposition design. Journal of Cleaner Production, 147, 175-186. https://doi.org/10.1016/j.jclepro.2017.01.081.

Bryman, A. \& Bell, E. (2014). Research Methodology: Business and Management Contexts. Cape Town: Oxford University Press.

Cant, M. (2012). Challenges faced by SMEs in South Africa: Are marketing skills needed? International Business \& Economics Research Journal, 11(10), 1107-1116. https://doi.org/10.19030/iber.v11i10.7256.

Charman, A. \& Piper, L. (2012). Xenophobia, criminality and violent entrepreneurship: violence against Somali shopkeepers in Delft South, Cape Town, South Africa. South African Review of Sociology, 43(3), 81-105. https://doi.org/10.1080/21528586.2012.727550.

Charmaz, K. (2014). Constructing Grounded Theory: A Practical Guide Through Qualitative Analysis. London: Sage Publications.

Chen, J., Liu, L. \& Wang, Y. (2020). Business model innovation and growth of manufacturing SMEs: a social exchange perspective. Journal of Manufacturing Technology Management, 32(2), 290-312. https://doi.org/10.1108/JMTM-03-2020-0089. 


\section{ENTREPRENEURSHIP AND SUSTAINABILITY ISSUES}

ISSN 2345-0282 (online) http://jssidoi.org/jesi/ 2021 Volume 9 Number 1 (September)

http://doi.org/10.9770/jesi.2021.9.1(38)

Cicea, C., Popa, I., Marinescu, C. \& Stefan, S. (2019). Determinants of SMEs' performance: evidence from European countries. Economic research, 32(1), 1602-1620. https://doi.org/10.1080/1331677X.2019.1636699.

Collis, J. \& Hussey, R. (2014). Business Research: A Practical Guide for Undergraduate and Postgraduate Students, $4^{\text {th }}$ Edition. London: Palgrave Macmillan.

Ebert, C. (2016). Value-Driven Process Management. In Managing Software Process Evolution (pp. 61-75). Springer, Cham. https://doi.org/10.1007/978-3-319-31545-4_4

Elizabeth, C., Popoola, B. A. \& Popoola, O. O. (2020). The influence of entrepreneurial training, access to finance, entrepreneurial capacity, entrepreneurial atmosphere on youth entrepreneurship. African Journal of Business and Economic Research, 15(1), 81-107. https://doi.org/10.31920/1750-4562/2020/15n1a4.

Elo, M. (2016). Typology of diaspora entrepreneurship: case studies in Uzbekistan. Journal of International Entrepreneurship, 14(1), 121155. https://doi.org/10.1007/s10843-016-0177-9.

Fernandes, S.S., Martins, L.D., Campese, C. \& Rozenfeld, H. (2019). Representing the Value Proposition of Product-Service Systems (PSS) in a Value-Based Perspective, in Proceedings of the 22nd International Conference on Engineering Design (ICED19), Delft, Netherlands, 5-8 August 2019.

Frow, P., \& Payne, A. (2011). A stakeholder perspective of the value proposition concept. European Journal of Marketing, 45(1-2), 223240. https://doi.org/10.1108/03090561111095676.

Gilles, N. \& Christine, L. C. (2016). The Sustainable Value Proposition of PSSs: The Case of ECOBEL 'shower Head', Procedia CIRP. Elsevier B.V., Vol. 47, pp. 12-17. https://doi.org/10.1016/j.procir.2016.03.043.

Gupta, N. \& Mirchandani, A. (2018). Investigating entrepreneurial success factors of women-owned SMEs in UAE. Management Decision, 56(1), 219-232. https://doi.org/10.1108/MD-04-2017-0411.

Hare, C. \& Walwyn, D. (2019). A qualitative study of the attitudes of South African spaza shop owners to coopetitive relationships. South African Journal of Business Management, 50(1), 1-12. https://doi.org/10.4102/sajbm.v50i1.1295.

Herrington, M. \& Kew, P. (2016). Global Entrepreneurship Monitor, South Africa Report 2015/16: Is South Africa Heading for an economic meltdown? [Online] Available from: http: //www.gemconsortium.org/report. [Accessed 8 September 2017].

El Hussein, M. T., Kennedy, A., \& Oliver, B. (2017). Grounded Theory and the Conundrum of Literature Review: Framework for Novice Researchers. The Qualitative Report, 22(4), 1198-1210. https://doi.org/10.46743/2160-3715/2017.2661

Key, M., Clark, T., Ferrell, O. C., Pitt, L. \& Stewart, D. (2017, May). Marketing's Theoretical and Conceptual Value Proposition: An Abstract. In Academy of Marketing Science Annual Conference (pp. 255-256). Springer, Cham. https://doi.org/10.1007/978-3-319-660233_92.

Kirchmer, M. (2017). Small and Medium Enterprises Need Value-Driven BPM. In High Performance through Business Process Management (pp. 169-182). Springer, Cham. https://doi.org/10.1007/978-3-319-51259-4_10.

Kowalkowski, C. (2011). Dynamics of value propositions: insights from service-dominant logic, European Journal of Marketing, 45(1/2), 277-294. https://doi.org/10.1108/03090561111095702.

Kowalkowski, C., Persson Ridell, O., Röndell, J. G., \& Sörhammar, D. (2012). The co-creative practice of forming a value proposition. Journal of Marketing Management, 28(13-14), 1553-1570. https://doi.org/10.1080/0267257X.2012.736875.

Martin, C. J. (2016). The sharing economy: A pathway to sustainability or a nightmarish form of neoliberal capitalism? Ecological Economics, 121, 149-159. https://doi.org/10.1016/j.ecolecon.2015.11.027.

Moeuf, A., Lamouri, S., Pellerin, R., Tamayo-Giraldo, S., Tobon-Valencia, E. \& Eburdy, R. (2020). Identification of critical success factors, risks and opportunities of Industry 4.0 in SMEs. International Journal of Production Research, 58(5), 1384-1400. https://doi.org/10.1080/00207543.2019.1636323. 


\section{ENTREPRENEURSHIP AND SUSTAINABILITY ISSUES}

ISSN 2345-0282 (online) http://jssidoi.org/jesi/ 2021 Volume 9 Number 1 (September)

http://doi.org/10.9770/jesi.2021.9.1(38)

Musara, M. \& Fatoki, O. (2011). The effectiveness of business development services providers (BDS) in improving access to debt finance by start-up SMEs in South Africa. International Journal of Economics and Finance,3(4), 208-216. https://doi.org/10.5539/IJEF.V3N4P208.

Nkongolo-Bakenda, J.M. \& Chrysostome, E.V. (2013). Engaging diasporas as international entrepreneurs in developing countries: in search of determinants. Journal of International Entrepreneurship, 11(1), 30-64. https://doi.org/10.1007/s10843-012-0098-1.

Osterwalder, A., Pigneur, Y., Bernarda, G. \& Smith, A. (2014). Value proposition design: How to create products and services customers want. John Wiley \& Sons.

Ostrovsky, Y. \& Picot, G. (2020). Innovation in immigrant-owned firms. Small Business Economics, 1-18. https://doi.org/10.1007/s11187020-00376-2.

Payne, A. \& Frow, P. (2014). Deconstructing the value proposition of an innovation exemplar. European Journal of Marketing. 48(1), 237270. https://doi.org/10.1108/EJM-09-2011-0504.

Payne, A., Frow, P. \& Eggert, A. (2017). The customer value proposition: evolution, development and application in marketing. Journal of the Academy of Marketing Science, 45(4), 467-489. https://doi.org/10.1007/s11747-017-0523-z.

Prashantham, S., Kumar, K. \& Bhattacharyya, S. (2019). International new ventures from emerging economies: Network connectivity and legitimacy building. Management and Organization Review, 15(3), 615-641. https://doi.org/10.1017/mor.2019.22.

Priem, R. L., Wenzel, M. \& Koch, J. (2018). Demand-side strategy and business models: Putting value creation for consumers center stage. Long range planning, 51(1), 22-31. https://doi.org/10.1016/j.lrp.2017.07.007.

Radipere, S. \& Dhliwayo, S. (2014). An analysis of local and immigrant entrepreneurs in South Africa's SME sector. Mediterranean Journal of Social Sciences, 5(9), 189-189. https://doi.org/10.5901/mjss.2014.v5n9p189.

Satar, N. S., Dastane, O. \& Ma'arif, M. Y. (2019). Customer value proposition for E-commerce: A case study approach. International Journal of Advanced Computer Science and Applications (IJACSA), 10(2), 454-458. https://doi.org/10.14569/IJACSA.2019.0100259.

Schachtebeck, C., Groenewald, D. \& Nieuwenhuizen, C. (2019). Intrapreneurial Orientation in SMEs: A South African Perspective. EuroEconomica, 38(2): 243-256. http://dx.doi.org/10.4102/ac.v19i2.638.

Schor, J. (2014). Debating the sharing economy. Journal of Self-Governance \& Management Economics, 4(3), 7-22.

Sengupta, A., Bamel, U. \& Singh, P. (2015). Value proposition framework: implications for employer branding. Decision. 42(3), 307-323. https://doi.org/10.1007/s40622-015-0097-x.

Skålén, P., Gummerus, J., Von Koskull, C. \& Magnusson, P. R. (2015). Exploring value propositions and service innovation: a servicedominant logic study. Journal of the Academy of Marketing Science, 43(2), 137-158. https://doi.org/10.1007/s11747-013-0365-2.

Strauss, A. L. \& Corbin, J. (2008). Basics of qualitative research: Techniques and procedures for developing grounded theory, $3^{\text {rd }}$ Edition. Thousand Oaks, CA: Sage Publications.

Takyi, L. \& Naidoo, V. (2020). Innovation and Business Sustainability Among SMEs in Africa: The Role of the Institutions. In Sustainability in the Entrepreneurial Ecosystem: Operating Mechanisms and Enterprise Growth (pp. 50-74). IGI Global. https://doi.org/10.4018/978-1-7998-3495-3.ch003.

Tengeh, R. (2013). Advancing the case for the support and promotion of African immigrant-owned businesses in South Africa. Mediterranean Journal of Social Sciences, 4(2), 347-359. https://doi.org/10.5901/mjss.2013.v4n2p347.

Trkman, P. (2019). Value proposition of business schools: More than meets the eye. The International Journal of Management Education, 17(3), 1-11. https://doi.org/10.1016/j.ijme.2019.100310.

van Scheers, L. \& Mmatli, W. (2020). Developing and Managing Product Development for Small and Medium Enterprises (SMEs) in South Africa. Economica, 15(7), 263-277. 


\section{ENTREPRENEURSHIP AND SUSTAINABILITY ISSUES}

ISSN 2345-0282 (online) http://jssidoi.org/jesi/ 2021 Volume 9 Number 1 (September)

http://doi.org/10.9770/jesi.2021.9.1(38)

Vorbach, S., Müller, C. \& Poandl, E.M. (2019). Co-creation of Value Proposition: Stakeholders Co-creating Value Propositions of Goods and Services. In Redlich, T., Moritz, M. Wulfsberg, J.P (Eds). Co-Creation: Reshaping Business and Society in the Era of Bottom-up Economics. Cham: Springer. https://doi.org/10.1007/978-3-319-97788-1_5.

Wallendorf, M. \& Belk, R. W. (1989). Assessing trustworthiness in naturalistic consumer research. In E. C. Hirschman (Ed.), Interpretative consumer research (pp. 69-84). Provo: Association for Consumer Research.

Webster, F. E. \& Lusch, R. F. (2013). Elevating marketing: marketing is dead! Long live marketing! Journal of the Academy of Marketing Science, 41(4), 389-399. https://doi.org/10.1007/s11747-013-0331-z.

Wruk, D., Oberg, A., Klutt, J. \& Maurer, I. (2019). The presentation of self as good and right: How value propositions and business model features are linked in the sharing economy. Journal of Business Ethics, 159(4), 997-1021. https://doi.org/10.1007/s10551-019-04209-5.

Zott, C. \& Amit, R. (2013). The business model: A theoretically anchored robust construct for strategic analysis. Strategic Organization, 11(4), 403-411. https://doi.org/10.1177/1476127013510466.

Mazanai MUSARA is a lecturer in Entrepreneurship at the University of Mpumalanga, South Africa. He holds a PhD in Business Management from the University of Johannesburg.

ORCID ID: https://orcid.org/0000-0002-2801-3458

Cecile NIEUWENHUIZEN is a Professor and DHET-NRF SARchl Chair in Entrepreneurship Education in the College of Business and Economics at the University of Johannesburg, South Africa

ORCID ID: https://orcid.org/0000-0003-4925-3212

Make your research more visible, join the Twitter account of ENTREPRENEURSHIP AND SUSTAINABILITY ISSUES: @Entrepr69728810

Copyright () 2021 by author(s) and VsI Entrepreneurship and Sustainability Center This work is licensed under the Creative Commons Attribution International License (CC BY). http://creativecommons.org/licenses/by/4.0/

CC) (i) Open Access 